\title{
ROMANIA AND THE EURO: THE STATE OF THE DEBATE
}

\author{
Radu Șimandan ${ }^{1 *}$, Beatrice Leuștean ${ }^{2}$, Răzvan Dobrescu ${ }^{3}$ \\ ${ }^{1}$ Asst. Lecturer Dr., University Politehnica of Bucharest, Romania, radu.simandan@upb.ro \\ ${ }^{2}$ Lecturer Dr., University Politehnica of Bucharest, Romania, beatrice.leustean@upb.ro \\ ${ }^{3}$ Lecturer Dr., University Politehnica of Bucharest, Romania, razvan.dobrescu@upb.ro \\ ${ }^{*}$ Corresponding author
}

\begin{abstract}
As a member of the European Union (EU), Romania is required to adopt the European single currency once it fulfils all the convergence criteria. As of June 2017, the national currency has not yet joined the preparatory two-year phase (the Exchange Rate Mechanism - ERM) necessary for the adoption of the euro and a certain target date has not been established. Over the years, different target dates have been officially set and communicated to the public, only to be later deemed unrealistic and postponed.

The aim of this study is to present the state of the debate regarding the adoption of the euro and to describe how the main arguments have developed in recent years. To this end, academic studies both by Romanian and foreign specialists that treat the issue of euro adoption by Romania are reviewed and analyzed. Also, a number of recent typical popular press articles on this subject are presented and investigated. In addition, public positions recently taken by important political players and appointed officials such as the ones in the Central Bank are discussed and the core arguments found in these discourses are highlighted.

Insights from the political discourse analysis body of literature are used to decipher the policy-related meaning of the text and context that accompany public declarations of some key political actors. The main storylines that can be found in this literature are identified and analyzed in terms of economic and political reasoning as well as rhetoric.
\end{abstract}

Keywords: euro, economic convergence, Romania.

\section{INTRODUCTION}

Romania has been a member of the European Union (EU) since January 2007. As is the case with any member of the EU, Romania is required to adopt the European single currency once it fulfills a set of preestablished criteria.

Over the years, different target dates have been officially set and communicated to the public, only to be later deemed unrealistic and postponed. The year 2010 has been the first official target for adoption but was 
later dropped. Economists criticized the setting of an unrealistic target, arguing that this could have promoted loans denominated in euro, thus exposing the public to foreign exchange risk. Similarly, the year 2019 has been announced as a possible target, but tacitly abandoned.

The Romanian public has constantly been among the most enthusiastic supporters of euro adoption. Sixtyfour percent of citizens favor the introduction of the euro as a single currency, the greatest percentage in the seven newer countries members of the EU (EC 2016). Related to governmental actions for adoption, the Government periodically publishes a Convergence Programme in which concrete measures towards this end are presented. The official commitment to euro adoption is usually stressed in these reports.

The degree of similarity with euro zone economies has been a constant issue in discussions about euro adoption in Romania. Since the average per-capita GDP (expressed as the purchasing power standards) represented around 55 percent compared to EU-28in 2015 (which is a significant increase from 52 percent in 2010), the Romanian economy has a long way until it becomes comparable to euro zone economies.

\section{THE ECONOMICS OF EURO ADOPTION: THE ECONOMIC FRAMEWORK VS. THE INSTITUTIONAL-POLITICAL FRAMEWORK}

The economics of a single currency adoption has been habitually framed in the optimum currency area theory devised by Mundell (1961). In this theoretical model, a country's suitability to become part of a currency area is judged against a number of strictly economic conditions, such as: business cycle synchronization with the member states of the currency area, the degree of trade integration, labor mobility and the level of fiscal transfers with current members.

Mundell's conceptual framework dominated the scientific debate on the EMU. The convergence criteria stipulated by the Maastricht Treaty stem partially from this theory. They aim at attaining some macroeconomic conditions compatible to a sustainable common currency area. Abandoning the independent use of monetary policy emphasizes the need for a long-term commitment to strict convergence criteria. An implication of this framework for analysis is that deep structural and institutional reforms are considered necessary for countries that have rigid markets, prices and wages (Bukowski 2006).

In an academic debate environment generally optimistic towards euro adoption, Marinaș (2013) thoroughly analyzes the risks posed by this choice. The Romanian economy is insufficiently convergent from a structural point of view with euro area economies. Even if the degree of business cycle synchronization is currently growing, this process is unsustainable if structural differences perpetuate. Under these circumstances, the absence of a monetary instrument for absorbing shocks becomes significant. Given that Romania's external competitiveness is still quite weak, adopting the euro would expose the economy to painful labor costs adjustments and a boom-bust cycle since labor costs can be adjusted more easily during expansion periods. The high rigidity of the Romanian labor market poses similar difficulties. Establishing an appropriate EUR/RON conversion rate is a further challenge, as is the use of the fiscal anti-cyclical instrument. Although adopting the euro provides the grounds for lower transaction costs, an intensification of trade and an increase in investment, this is conditional to reforming the business environment through domestic efforts. Until these weaknesses of the Romanian economy (especially the structural divergence) show some improvement, adopting the single currency is rather a bad idea.

Păun (2016) takes a more principled path to show that the euro is a fiat currency to the same degree as were the national currencies of states prior to EMU accession and of the present-day states outside of the euro zone. The choice that countries required to adopt the euro are presented with is therefore to replace one fiat currency with another. In addition, there are reasons to believe that the euro is even easier to produce that former competing national currencies were, such as the fact that the ECB enjoys a greater political support from EU policymakers and bureaucrats and a looser democratic control by elected bodies (p. 90). Since the monetary system remains a fractional reserve system, switching to the euro does not reset the fundamental mechanisms of money creation. Euro adoption is not a revolutionary change as its proponents depict it. Both nominal and real convergence criteria are deemed as arbitrarily defined and have no place in debates on this issue. The easy money policy lately adopted by the ECB poses a supplementary difficulty, given that the effects of such policy are not easy to assess on a large territory. Since issuing a fiat currency is essentially a political enterprise, the euro is a political currency and euro adoption is a political process with a very weak relation to economic realities. Therefore, the case in favor of euro adoption by Romania is weaker and more superficial than commonly presented.

The degree of fulfillment of the Maastricht nominal criteria for joining the euro zone has been analyzed in number of articles (e.g., Apetri \& Mihalciuc 2010, Apetri et al. 2010, Dovleac \& Broju2013, lalomițianu \& Boldeanu 2017, lancu 2008a, Năftănăilă et al. 2017). The risks to internal stability posed by giving up the monetary anti-shock tool are usually stressed (e.g., Năftănăilă et al. 2017), as is the necessity to improve the 
use of sole remaining policy tool: the fiscal policy. Another idea usually emphasized in these studies is that a sustainable practicability of the Maastricht framework requires internal reform efforts. The institutional business environment is in need of reforms, the structural composition of the Romanian economy being identified as the main weakness. The financial and economic crisis is generally recognized as a game changer, since meeting a list of requirements may become problematic in a depressed economy. The risk of exceeding the budget deficit target in 2016 is also recognized (lalomițianu \& Boldeanu 2017). Putting into practice the assumed framework is customarily regarded as an economic necessity, not strictly as a condition for adopting the euro (e.g., Dovleac \& Broju 2013).

The most recent Convergence Report issued jointly by the European Central Bank and the European Commission (ECB 2016) evaluates Romania's state of nominal economic convergence in positive terms. The inflation rate was "well below the reference value of $0.7 \%$ for the criterion on price stability"; the government general "deficit and debt complied with the Maastricht criteria" (although Romania is "at risk of a significant deviation in both 2016 and 2017"); the national currency "traded under a flexible exchange rate regime involving a managed floating of the currency's exchange rate" (although it is not part of ERM II), while the "current and capital account has improved substantially over the past decade"; long-term interest rates in Romania were $3.6 \%$ on average and thus below the $4.0 \%$ reference value for the interest rate convergence criterion". However, even though the convergence criteria are currently met, "[a]chieving an environment that is conducive to sustainable convergence in Romania requires stability-oriented economic policies and wideranging structural reforms". Moreover, the institutional environment is not yet fully adapted, as the requirements from the previous report have been translated into law: "Romanian law does not comply with all the requirements for central bank independence, the monetary financing prohibition and legal integration into the Eurosystem" (ECB 2016, pp. 61-62).

The arguments one may find in academic debates are more or less accurately translated into political debates. The popular press cites the chief of the central bank stating in April 2017 at a scientific conference, "The Romanian economy has been meeting the Maastricht criteria continuously since July 2015". However, "It is important that economic policies conducted by Romanian authorities assure that these conditions will also be met in the future", he added (Bănciulea 2017).

Given that the criteria for convergence specified in the Maastricht Treaty are clear-cut economic conditions formalized in quantitative benchmarks, assessing the degree of fulfillment of those conditions should not pose any difficulty and should not be a matter of academic disagreement. In contrast, real convergence has a more controversial nature. There is neither a universally accepted definition nor a quantitative assessment for the real convergence. The standard of living is the underlying concept used to assess the degree of real convergence, while the per-capita GDP is the most commonly used indicator. In the context of euro adoption, real convergence is presented as a way of decreasing an economy's exposure to asymmetric shocks, given that an independent monetary policy is abandoned. The "bigger picture" provided by the real convergence criteria gained ground in the debate about euro adoption.

Real convergence of the Romanian economy has been increasingly analyzed in recent years in academic papers (e.g., Arratibel et al., 2008 Duican 2015, lancu 2008b, 2009) as well as in popular debate and political communication. The discussion has been extended to some degree beyond the rigid Maastricht criteria to incorporate such facts as the economic similarity with euro zone members and the overall performance of the economy.

Dulgheriu (2015) argues that the criteria that should be taken into account as determining the real convergence of the Romanian economy (in addition to the traditional per-capita GDP) are the following: the openness of the economy; the share of the bilateral trade relations with EU member states in total foreign trade; and the composition of the economy (expressed by the percentage of the main sectors in the GDP: agriculture, industry and services). Based on such indicators, the Romanian economy shows a low degree of convergence. A further problem may be the fact that fiscal policy measures needed to increase real convergence may endanger nominal convergence. An unexpected trade-off relation between nominal and real convergence is thus identified.

Szeles \& Marinescu (2010) find that the Central and Eastern European countries (Romania included) have experienced convergent economic growth in the previous decade, driven mainly by labor productivity and participation to international trade.

Triandafil (2011) also shows the limitations of the nominal convergence criteria in the post financial crisis era. The "nominal economy" (e.g. financial flows) became disconnected from the "real economy" (e.g. production of goods and services, and standards of living) as a result of the turmoil. Business cycles in the euro zone economies vs. non-euro economies in the EU became less synchronized. A new, more complex set of indicators, both quantitative and qualitative, is needed to assess the stage of the economy on its way to 
convergence. Among the suggested indicators are the following: percentage of population living below subsistence level, broken down by categories of the population; index of pollution level in urban and rural environment; the share of non-conventional energy sources correlated with annual energy consumption; recycling and reuse rate of waste; Gini coefficient of income inequality by geographical areas.

The governor of the central bank has repeatedly warned that following the nominal convergence criteria is not enough (Isărescu 2007, 2008, 2015). The basic suggestion is that the long-term aim of the economic policy should be to steer the Romanian economy as to insure a high degree of similarity to the euro zone economies. The main challenges identified are the low level of trade with the EU countries, the structure of this trade (low added-value products taking a large share of exports), and the structure of the Romanian economy (with a low level of services relative to the GDP). Among the aims of structural reforms is to insure a greater flexibility of the labor market (Isărescu 2008). Even though the productivity of labor has rapidly increased in recent years, the rate of growth of wages has been even higher, a dynamic that may endanger external competitiveness and put pressure on the exchange rate. The approach to euro adoption has drastically shifted in the wake of the sovereign debt crisis. Abundance of capital, low risk aversion and a rapid economic convergence specific to the pre-crisis environment became reversal of capital flows, high risk aversion and slow or even reverse economic convergence. As a consequence, adopting the euro has turned from a priority to a fact regarded as problematic. The bottom line: "Recent experience seems to favor a longer waiting period before joining the single currency" (Isărescu 2015, p. 17).

The overall implication suggested by the real convergence literature is that adoption should happen only after a larger set of conditions are met. The nominal criteria are not sufficient to insure a sustainable convergence. Increasing the degree of similarity between the Romanian and euro zone economies has been increasingly presented a necessary pre-condition for a successful euro adoption. However, quantitative benchmarks for this process have never been made public.

The arguments from the real convergence debate began to appear in political communication. "Let's make sure that this monetary convergence will be made in parallel with the income convergence. The adoption of the euro can only be made after, we believe, also the income of Romanians will be close to those in other EU member states", prime minister Grindeanu stated during a meeting of the inter-ministerial committee for the adoption of the euro (Gheorghe 2017). Emphasizing such indicators as the standard of living and the income level, political decision makers implicitly offered a rationale for the frequent rescheduling of the adoption deadline.

To summarize the above discussion, we argue that there are two competing frameworks for analyzing the adoption of the single currency: the economic framework and the institutional-political framework. The economic framework draws to some extent on the optimum currency area theory to assess how close Romania is to forming an optimal monetary union with the current members and to judge the overall feasibility and desirability of the euro. The institutional-political framework is based on the criteria set forth in the Maastricht treaty. The standard objective of studies set in this framework is to analyze the degree of fulfillment of these criteria and occasionally to assess the sustainability of this enterprise. Slightly departing from this pattern, several academic and political discussions analyze the real convergence between the Romanian and the core EMU economies.

We find that the majority of studies dealing with euro adoption by Romania take an institutional-political approach, with very few references to hard economic arguments. Both academics and popular press analysts put a lot of emphasis on the nominal convergence criteria and Romania's duty to conscientiously meet the requirements. Real convergence criteria also received a great deal of attention, stimulating debates about the degree of economic similarity and the pre-conditions for euro adoption.

\section{A COMPLEMENTARY VIEW ON THE DEBATE: RHETORIC AND DISCOURSE ANALYSIS}

\subsection{Rhetoric and Storylines of Euro Adoption}

Contemporary economics is rooted in a logical-positivist philosophy that values mathematical formalization, quantification, and statistical tests. McCloskey offered her critique of this position in her famous Rhetoric of economics (1985). Whether economists recognize it or not, economics make use of metaphors and stories. It is at the same time scientific and rhetorical. Identifying and analyzing the rhetorical content of economics is not equivalent to seeking to discredit its findings. Rather, it is an exercise in discovering the means by which economics usually advances.

Applying McCloskey's ideas to the problem in question, we argue that the economics of euro adoption is at the same time scientific and rhetorical. Adopting the single currency has a rich rhetoric and studying this 
IJASOS- International E-Journal of Advances in Social Sciences, Vol. III, Issue 8, August 2017

rhetoric, far from being a waste of time, has the potential of revealing some aspects that traditional economics, with its fixation on strict methodology and mathematical modeling, may miss. Adopting a new currency as the sole legal medium for making payments has a human dimension that is seldom studied by traditional economics.

Discourse analysis investigates how ideas and realities such as economic institutions and organizations are created and preserved through talk, text, and action. Identifying and analyzing discourse has nowadays become a common concern in humanities and social sciences (Fairclough 2003, p. 123).

The storyline is the basic linguistic mechanism of discourse. Hajer (1995, p. 56) defines the storylines as a type of narrative "that allows actors to draw upon various discursive categories to give meaning to specific physical or social phenomena". In this conception, recognizing the interpretative character of a storyline is key to understanding its functions. People do not usually appeal to comprehensive social theories in order to understand social reality, but rather use storylines as convenient collections of rules of thumb.

Unsurprisingly, adopting the euro has been studied in the modernist framework of the mainstream economic science. Investigating the rhetoric of economics as well as the discourse of politicians related to euro adoption may reveal some facets of this process that are hidden from the official positivist economic science. Therefore, we have identified a few storylines related to euro adoption in popular press economic debates and political discourse. We shall proceed to present and analyze these storylines.

\section{Euro as a discipline-enhancing mechanism}

A commonly held view is that a sustainable currency union requires economic discipline both at the level of the union and individual member states. It particularly needs that national governments act in a sound manner in the fiscal sphere. Absent a discipline-enhancing framework, national governments in a currency union have an incentive to be reckless and run large deficits and debt: they will receive the benefits but share the risks with the other members. The solution adopted by the framers of the EMU was a set of fiscal rules that members stares are required to adopt and maintain. Fiscal discipline is thus promoted through EU legislation and intergovernmental treaties. More recently, the push for a fiscal union in the EU has the same theoretical source: fiscal policy conducted at national level plays an essential role in a monetary union and the need for a joint conduct of such tool is clear.

In popular press and political communication, this basic economic reasoning translated into a storyline that emphasizes the role of the single currency as a discipline-promoting mechanism. Being part of the euro family would require a certain degree of conformity from local politicians, whether they like it or not. Political players use to praise the quality of euro zone membership as changing the current state of affairs and uphold fiscal discipline. The governor of the central bank has constantly warned that entering the euro zone requires discipline and responsibility from the part of policymakers. "Fiscal discipline" became a key phrase in economic communication stemmed from the central bank. However, as the chief economist of the NBR argued, "(...) the discipline imposed by the market is far more constraining than the discipline of EU organisms" (Lazea 2015). Therefore, the market discipline is something to be avoided; losing to some degree the national sovereignty in favor of EU organisms (which commonly display "a willingness to negotiate and compromise") is preferable.

\section{Adopting the euro as giving up a domestic policy tool}

In both the academic literature and popular press debates, it is widely accepted that countries that adopt a single currency resign from using their own monetary policy, including exchange rate, as a tool for macroeconomic stabilization. In case of economic shocks, the array of economic policy instruments available to authorities turns out to be extremely narrow. Only fiscal policy remains to be reflected on, although the efficiency of this tool is generally regarded as limited.

This argument has been employed heavily during the sovereign debt crisis, especially with regard to some countries severely hit by the predicament such as Greece, Ireland and Portugal. Confronted with a recession, countries that are fortunate enough to have their own central bank can use money creation to help promote recovery. Monetary policy has thus been unwisely "outsourced" to a cold, unreachable organization, namely the ECB. Lacking a national, internally managed currency is equivalent to depending on foreigners for the provision of a vital good - economic stability and steady growth.

Surprisingly, few of the academic articles analyzed in this paper explicitly as a downside of an eventual euro zone membership. Marinaș (2013) argues that the stabilizing quality of the (domestic) monetary policy should be assessed before and after euro adoption and considers the abandonment of the monetary tool (and the ensuing enlarged aggregate demand shocks) as the main cost of adopting the euro by Romania. This raises serious questions for a peripheral country, especially in view of the fact that due to its ultimate 
political nature, the ECB is more prone to adopt policies that favor the most important economies of the union. On the other hand, this storyline has been relatively common in political communication. "Adopting the euro would entail giving up monetary and exchange rate policies", the vice-governor of the National Bank of Romania (NBR) warned in 2009 during a conference dedicated to an eventual unilateral euro adoption (Chiru 2009). "The convergence process would remain the sole responsibility of the fiscal policy", he added.

\section{Euro adoption as a country project}

A recent entry in the Romanian journalistic and political discourse, the country project is commonly referred to as a project that aims at formulating some long-term social and economic objectives at national level. Last attempt to formulate a country project has taken place in October 2016, when President lohannis set up a committee in charge with drawing up "Romania's best ever country project" (Peia 2016). Under the headline "Competitive Romania", the project aims at laying down the country's political and economic objectives along with concrete governmental actions to reach those objectives.

The initiative has been criticized for its lack of realism and for failing to involve all relevant parties in the process. It has also been argued that a much more appropriate country project would be a clear path towards euro adoption. The wide array of constraints put in place by euro adoption would have sizeable consequences and is equivalent to a comprehensive country project, at least in the economic sphere (Anghel 2016).Adopting the single currency must therefore be put in a wider perspective and seen as a return of the Romanian people in the European family. Assuming the acquis communautaire should overcome the declarative phase specific to the Romanian political elite after the EU accession and a new, more straightforward chapter should be opened through euro adoption (Cerna 2016).

\section{Euro zone membership as a place at the decision table}

A new storyline seems to be taking shape in political discourse related to euro area accession. Confronted with increased difficulties, political leaders from the largest EU economies advanced their project to create a multi-speed Europe, spurring newer EU member states to voice concerns about their status in the new framework.

The idea of a multi-speed Europe has been incorporated in a storyline that links the euro zone membership to a perceived access to the decision making process in the EU. The euro zone seems to work like a club: the select few members of this group make important decisions for the entire EU. Joining the club would ensure a place at the decision table. Former President Băsescu clearly articulated this point of view: "We must adopt the euro by 2019 in order to avoid becoming a second class country", he said (Mănoiu 2017).

\subsection{Storylines Absent From Public Debate}

Reviewing the academic and popular literature on euro adoption by Romania it is surprising to learn that a number of storylines that have been commonly employed in EMU member states in the wake of the crisis appear to be missing from the Romanian public debate. This is probably the result of the general enthusiasm for EU institutions and the overall low level of public debate related to euro adoption.

For instance, the case of Greece has seldom been used as a cautionary tale against Romania's planned euro zone accession. In "The euro did it" storyline, the single currency is depicted as having facilitated or even caused the Greek crisis. As a consequence of euro adoption, national interest rates converged to the lower euro zone level, making it irresistible for the Greek government to borrow in international markets. This contributed to the accumulation of debt - the story goes - with market forces being unable to accurately assess the risk. Furthermore, once the (exogenously generated) crisis made its debut, German and Dutch investors began to send their money back home, with no export boost normally associated with a cheaper national currency. Therefore, due to the single currency, the Greek government officials found themselves having their hands tied, with no tools available to counteract the effects of the crisis. The clear-cut conclusion: Greek politicians made an enormous miscalculation, giving up "monetary independence" in exchange for short-term benefits associated with euro zone membership.

We could identify only one academic article that specifically aims at drawing some lessons from the Greek experience that are relevant for Romanian economic policymaking (Tache 2010). In an unambiguous connection with the "Readiness of the economy" and the "Giving up a policy tool" storylines, the author's warning is that "overly ambitious" efforts to join the euro zone could result in high costs in terms of vulnerability in absence of a monetary and exchange rate policy tools (p. 185). The institutional-political view takes center stage, since it is the author's judgment that the nominal convergence criteria became more difficult to accomplish due to the economic downturn. Moreover, she argues that in the light of the Greek experience, European policymakers will likely be less enthusiastic to accept new euro zone members. As for popular press stories, a handful of articles treat the connections between the Greek crisis and Romania's 
future euro zone membership, only to bemoan the fact that the dire straits in Greece could deter Romania's efforts to join the euro zone. Here, too, the willingness of the politicians from the euro core countries to team up with a peripheral country is at the center of the argument. Little is said about the opportunity for Romania to enter the euro zone.

Similarly, the argument related to monetary sovereignty is quasi absent from Romanian public deliberation. In the rhetoric of sovereignty in the realm of money, the power to exercise a full control over the currency should remain the exclusive responsibility of a country's national government. By transferring the competence to issue the sole currency that they can legally use, members of the euro zone are said to have renounced their monetary sovereignty. "Returning to monetary sovereignty" by abandoning the "currency of bankers" (i.e. the euro) has thus become a common denominator of euroskeptics in the monetary sphere. Although in Romania the problem of sovereignty transfer to EU institutions has been discussed to some extent around the date of accession, the debate has not been extended to monetary arrangements. This is probably the effect of the high degree of confidence in EU institutions and of the fact that the Romanian public is relatively familiarized with day-to-day use of the single currency.

\section{CONCLUSIONS}

As of June 2017, Romania's intentions related to the adoption of the European single currency remain unclear. The most recent convergence program issued by the government (April 2016) does not provide a timetable for adoption, although it affirms the commitments of the Romanian authorities to eventually join the euro zone. The latest political declaration related to euro adoption is the one of the prime minister Grindeanu who announced that joining the euro zone will be taken into account only after the income of Romanians have become comparable to the one of the current members (Gheorghe 2017), although no quantitative assessment is given.

In the academic literature, the adoption of the euro by Romania has mainly been framed in the politicalinstitutional paradigm. From this viewpoint, Romania has the legal and moral obligation to enter the euro zone by accomplishing a set of written rules. The only detail to be internally debated upon and ultimately decided is the exact timeframe. The degree of fulfillment of the nominal convergence criteria has been extensively analyzed. Going beyond this framework of clear-cut rules, an increasing number of studies take a different path and propose to identify the ideal conditions for an efficient and sustainable adoption. Thus, the issue of real economic convergence (typically quantified in per-capita GDP) with euro zone member states has drawn the attention of academics and commentators.

The purely economic paradigm is much less widespread as a frame for debate. The main downside of this approach is that a principled debate on the advantages and disadvantages of euro zone membership is disappointingly weak. Among economic analysts, the consensus seems to be that policymakers' efforts should be focused on achieving a high degree of real convergence with the current euro zone member states in order to lower the impact on the economy. In popular press debate, the euro is understood as a requirement for becoming a member of this select club. A discussion of the legitimacy of adopting the single currency is also missing from public debate, leaving us to speculate that the euro may draw its legitimacy from the legitimacy of EU institutions.

\section{REFERENCE LIST}

Anghel, I. (2016). Profesorul Silviu Cerna: Cel mai bun proiect de ţară este adoptarea euro în 2019 [Professor Silviu Cerna: the best country project is adopting the euro by 2019]. Ziarul financiar. Sept. 23. Retrieved from: http://www.zf.ro/eveniment/profesorul-silviu-cerna-cel-mai-bun-proiect-de-taraeste-adoptarea-euro-in-2019-15743412.

Apetri, N.A., \& Mihalciuc, C. (2010).The analysis of Romania's integration stage in the economic and monetary union and of the nominal convergency criteria in the perspective of adopting. Studia Universitatis Vasile Goldiş, Arad - Seria Ştiinţe Economice, (1-1), 240-249.

Apetri, N.A., Sandu, G., \& Cibotariu, I.S. (2010). The analysis on the preparation degree of the Eastern Europe block states to adopt the unique currency. The Annals of The "Ştefan cel Mare" University of Suceava. Fascicle of the Faculty of Economics and Public Administration, 2(12).

Arratibel, O., Furceri, D. \& Martin, R. (2008). Real convergence in Central and Eastern European EU member states - which role for exchange rate volatility?. European Central Bank Working Paper, 929. 
Bănciulea, G. (2017). Isărescu: România îndeplinește din 2015 criteriile de la Maastricht [Isărescu: Romania has been meeting the Maastricht criteria since 2015]. Agerpress. Apr. 7. Retrieved from: https://www.agerpres.ro/economie/2017/04/07/isarescu-romania-indeplineste-din-2015-criteriile-de-lamaastricht-12-54-04.

Bukowski, S. (2006). The Maastricht convergence criteria and economic growth in the EMU. Quaderni del Dipartimento di Economia, Finanza e Statistica, 24.

Cerna, S. (2016). De ce să amânăm adoptarea euro? Trecerea la euro în 2019 este posibilă şi ar putea fi un moment astral în istoria recentă a României [Why postpone euro adoption? switching to the euro in 2019 is possible and it would be a turning point for Romania]. Ziarul financiar. Sept. 21. Retrieved from:http://www.zf.ro/opinii/de-ce-sa-amanam-adoptarea-euro-trecerea-la-euro-in-2019-este-posibilasi-ar-putea-fi-un-moment-astral-in-istoria-recenta-a-romaniei-15740711.

Chiru, L. (2009). Popa, BNR: Adoptarea unilaterala a euro nu este o optiune pentru Romania [Popa, NBR: A unilateral adoption of the euro is not an option for Romania]. Ziarul financiar. Apr. 30. Retrieved from: http://www.zf.ro/eveniment/popa-bnr-adoptarea-unilaterala-a-euro-nu-este-o-optiune-pentru-romania$\underline{4263247 .}$.

Dovleac, L. \& Broju, A. (2013). Why Is Romania still outside the euro zone?. Bulletin of the Transilvania University of Brasov. Economic Sciences. Series V, 6(1), 187-192.

Duican, E.R. (2015). Romania's path to the euro area - the importance of real convergence. Hyperion International Journal of Econophysics \& New Economy, 8(2), 497-509.

Dulgheriu, R.G. (2015). Nominal and real convergence in the euro area. SEA-Practical Application of Science, 1(7), 215-226.

ECB (2016). Convergence report. European Central Bank and European Commission. June. Retrieved from: https://www.ecb.europa.eu/pub/pdf/conrep/cr201606.en.pdf.

EC (2016). Flash Eurobarometer 440. Introduction of the euro in the Member States that have not yet adopted the common currency. European Commission. May. Retrieved from: http://ec.europa.eu/economy finance/articles/pdf/fl440 en.pdf.

Fairclough, N. (2003). Analysing Discourse: Textual Analysis for Social Research. London: Psychology Press.

Gheorghe, G. (2017). Grindeanu: Romania will adopt euro after Romanians' incomes reach EU level. Business Review. April 10. Retrieved from: http://www.business-review.eu/news/grindeanu-romaniawill-adopt-euro-after-romanians-incomes-reach-eu-level-134968.

GR (2016). Convergence program 2016-2019. Government of Romania. April. Bucharest. Retrieved from: http://ec.europa.eu/europe2020/pdf/csr2016/cp2016 romania en.pdf.

Hajer, M. (1995). The Politics of Environmental Discourse. Ecological Modernization and the Policy. Oxford: Oxford University Press.

Ialomitiianu, R.G. \& Boldeanu, T.F. (2017). Romania and the euro. An overview of Maastricht convergence criteria fulfilment. Revista Economică, 69(1), 74-87.

lancu, A. (2008a). Nominal convergence. Review of Economic and Business Studies, 2(17), 53-76.

lancu, A. (2008b). Real convergence and integration. Romanian Journal of Economic Forecasting, 9(1), 1528.

lancu, A. (2009). Convergența instituțională și integrarea în UE, Studii Economice. National Institute of Economic Research, 18.

Isărescu, M. (2007). România - Trecerea la euro [Romania - switching to the Euro]. In The South-East European Financial Forum, Bucharest (Vol. 17).

Isărescu, M. (2008). Probleme ale convergenţei reale în drumul spre Euro [Problems of real convergence on the path to euro]. Bucharest: Academia Română.

Isărescu, M. (2015). Nominal convergence versus real convergence. Paper presented at the Romania's Path towards Euro conference. Bucharest. April 20.

Lazea, V. (2015). Problemele zonei euro și mentalitatea balcanică [The problems of the euro zone and the Balkanic mentality]. Curs de guvernare. July 6. Retrieved from: http://cursdeguvernare.ro/valentin- 
lazea-problemele-zonei-euro-si-mentalitatea-balcanica.html.

Marinaş, M.C. (2013). The risks of euro adoption in Romania - an analysis based on ten criteria. Theoretical and Applied Economics, 20(1 (578)), 33-50.

Mănoiu, C. (2017). Traian Băsescu: România trebuie să intre în zona euro în 2019, ca să nu devină ţară de mâna a doua. [TraianBăsescu: Romania must join the euro zone in 2019 so it won't become a second class country]. Mediafax. Mar. 6. Retrieved from: http://www.mediafax.ro/politic/traian-basescuromania-trebuie-sa-intre-in-zona-euro-in-2019-ca-sa-nu-devina-tara-de-mana-a-doua-16184174.

McCloskey, D.M. (1985). The Rhetoric of economics. Madison, Wisconsin: The University of Wisconsin Press.

Mundell, R.A. (1961). A theory of optimum currency areas. American Economic Review, 51(4): 657-665.

Năftănăilă, C.A., Bragă, V.\& Zărnescu, O.M. (2017). Analysis of the convergence criteria in Romania for adopting the single currency and the Convergence Programme 2016-2019 regarding the monetary policy and the exchange rate. International Journal of Academic Research in Accounting, Finance and Management Sciences, 7(1), 162-169.

Păun, C. (2016). The adoption of euro in case of Romania: the main (counter) arguments. The Review of Social and Economic Issues, 1(3), 76-94.

Peia, F. (2016). lohannis: Romania's best ever country project to be finalised in about one year. Agerpres. Oct. 4. Retrieved from: https://www.agerpres.ro/english/2016/10/04/iohannis-romania-s-best-evercountry-project-to-be-finalised-in-about-one-year-12-40-19.

Szeles, M.R., \&Marinescu, N. (2010).Real convergence in the CEECs, euro area accession and the role of Romania. The European Journal of Comparative Economics, 7(1), 181-202.

Tache, I. (2010). The challenges of euro adoption in Romania: some lessons from the Greek experience. European Research Studies, 13(2), 171-186.

Triandafil, C.M. (2011). The analysis of the convergence criteria. Empirical perspective in the context of the sustainable character highlight (No. 111205). Working Papers of National Institute of Economic Research, Romanian Academy. 